Policy Research Working Paper 2855

\title{
Financial Crises, Financial Dependence, and Industry Growth
}

\author{
Luc Laeven \\ Daniela Klingebiel \\ Randy Kroszner
}

The World Bank

Financial Sector Strategy and Policy Department June 2002 


\begin{abstract}
Laeven, Klingebiel, and Kroszner investigate the link between financial crises and industry growth. They analyze data from 19 industrial and developing countries that have experienced financial crises during the past 30 years to investigate how financial crises affect sectors dependent on external sources of finance. Specifically, the authors examine whether the impact of a financial crisis on externally dependent sectors varies with the depth of the financial system. They find that sectors highly dependent on external finance tend to experience a greater contraction of value added during a crisis in deeper financial systems than in countries with shallower
\end{abstract}

financial systems. They hypothesize that the deepening of the financial system allows sectors dependent on external finance to obtain relatively more external funding in normal periods, so a crisis in such countries would have a disproportionately negative effect on externally dependent sectors. In contrast, since externally dependent firms tend to obtain relatively less external financing in shallower financial systems (and hence have relatively lower growth rates in such countries during normal times), a crisis in such countries has less of a disproportionately negative effect on the growth of externally dependent sectors.

This paper-a product of the Financial Sector Strategy and Policy Department-is part of a larger effort in the department to study the link between financial development and economic growth. Copies of the paper are available free from the World Bank, 1818 H Street NW, Washington, DC 20433. Please contact Rose Vo, room MC9-624, telephone 202-473-3722, fax 202-522-2031, email address hvo1@worldbank.org. Policy Research Working Papers are also posted on the Web at http:/ lecon.worldbank.org. The authors may be contacted at llaeven@worldbank.org, dklingebiel@worldbank.org, or randy.kroszner@gsb.uchicago.edu. June 2002. (26 pages)

The Policy Research Working Paper Series disseminates the findings of work in progress to encourage the exchange of ideas about development issues. An objective of the series is to get the findings out quickly, even if the presentations are less than fully polished. The papers carry the names of the authors and should be cited accordingly. The findings, interpretations, and conclusions expressed in this paper are entirely those of the authors. They do not necessarily represent the view of the World Bank, its Executive Directors, or the countries they represent. 


\title{
Financial Crises, Financial Dependence, and Industry Growth
}

\author{
Luc Laeven, Daniela Klingebiel and Randy Kroszner**
}

Preliminary draft

Keywords: financial crises, financing constraints, financial development, industry growth

\footnotetext{
** The authors are at the World Bank, the World Bank, and the University of Chicago, the Council of Economic

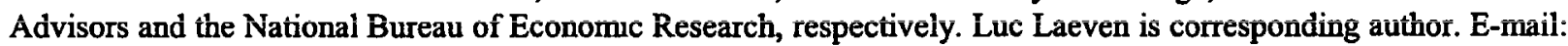
llaeven@worldbank.org. Tel. 202458 2939. We thank Stijn Claessens and Inessa Love for comments and Ying Lin for research assistance. The opinions expressed do not necessarily reflect those of the World Bank or the Council of Economic Advisors. Comments welcome.
} 



\section{Introduction}

While it is widely accepted that financial crises have adverse consequences for the economy as a whole, relatively little empirical work investigates the mechanisms by which financial crises generate problems in the real sector. In this paper, we analyze data from developed and developing countries that have experienced financial crises during the last 30 years to investigate the impact of crises on industrial growth in those countries. Understanding this impact is crucial for formulating policies to mitigate the costs of a crisis in the financial sector to the economy as a whole and contributes to the literature on the mechanisms linking financial shocks and real economic activity.

Much theoretical work has been done on how financial intermediaries and financial markets facilitate investment by firms and, hence, promote economic growth (see Levine (1997) and Rajan and Zingales (1998) for comprehensive overviews). Financial intermediaries and financial markets are generally thought to reduce moral hazard and adverse selection problems that can make raising external funds difficult and expensive for firms. Well-functioning and well-developed financial intermediaries and markets thus should disproportionately benefit firms that are most dependent on external funds to finance their growth. Conversely, crises in the financial sector should have a disproportionately negative impact on firms that rely heavily on external sources of finance. Specifically, we investigate whether the impact of a financial crisis on sectors dependent on external sources of financing varies with the level of development of the financial system. To cvaluate the empirical relevance of this theoretical mechanism, our empirical work focuses on the differential impact of financial crises on sectoral growth.

To preview our results, we find that in well developed and deep financial systems, sectors highly dependent on external finance tend to experience a greater contraction of value added during a 
crisis than do externailly dependent sectors in countries with shallower financial systems. As has been shown in previous work (Rajan and Zingales, 1998), the depth of the financial system appears to relax credit constraints to permit externally dependent sectors to grow faster during normal periods. To explain our results, we hypothesize that the depth of the financial system allows sectors dependent on external finance to obtain relatively more external funding in normal periods, so a crisis would have a disproportionately negative effect on externally dependent firms. In contrast, since externally dependent firms tend to obtain relatively less external financing in shallower financial systems (hence, we observe relatively lower growth rates in externally dependent sectors in such countries during normal times), a crisis in such countries has less of a disproportionately negative effect on the growth of these sectors. These results provide evidence supporting the existence of a "credit channel" through which firms dependent on external finance are harmed disproportionately during periods of financial distress.

In the next section, we provide a more detailed motivation for the approach we are taking and relate our work to the existing literature. Section III explains our econometric approach. Section IV then describes the data and, in particular, how we measure financial dependence and how we define financial crises. Section V contains the results. Section VI presents a number of caveats and qualifications with respect to our analysis. Section VII concludes.

\section{Motivations and relation to previous work}

There exists a large body of empirical literature on the link between finance and growth. Levine and Zervos (1998) study whether stock markets and banks promote economic growth. They find that measures of stock market liquidity and private sector credit have a strong independent 
effect on growth. Controlling for potential biases, Beck, Levine, and Loayza (2000) argue that there exists a clear empirical relation between the level of financial intermediary development and economic growth. They find that financial intermediaries exert a large, positive impact on total factor productivity growth, which feeds through to overall economic growth.

Jayarante and Strahan (1996) provide evidence that financial markets can directly affect economic growth by studying the relaxation of bank branch restrictions in the United States. They find that the rates of real, per capita growth in income and output increase significantly following intrastate branch reform. Improvements in the quality of bank lending, not increased volume of bank lending, appear to be responsible for faster growth.

Rajan and Zingales (1998) examine whether financial development facilitates economic growth by reducing the costs of external finance to firms. They find that industrial sectors that are relatively more in need of external finance develop disproportionally faster in countries with moredeveloped financial markets. As we discuss in more detail in the next section, they also overcome some of the identification problems embedded in standard cross-country growth regressions by using an interaction between a country characteristic (financial development of a particular country) and an industry characteristic (external financial dependence of a particular industry) in addition to country indicators and industry indicators.

Demirgüç=Kunt and Maksimovic (1997) show that well-developed financial systems are associated with externally financed firm growth. They also find that differences in legal systems affect firms' use of external financing to fund growth: in countries with efficient legal systems, a greater proportion of firms use long-term external financing.

There exists also a large empirical literature on the existence of a credit channel. This 
Iiterature tries to investigate to what extent adverse shocks to a borrower's net worth increase the cost of external financing, and through which channels these adverse effects occur. For households, Mishkin (1977) provides evidence of effects of household balance sheet conditions on consumer expenditures in the US during the 1973-75 depression.

Kashyap and Stein (2000) study the monetary-transmission mechanism using quarterly data on every insured US commercial bank for the period 1976-1993. They find that the impact of monetary policy on lending is stronger for banks with less liquid balance sheets, i.e., banks with lower ratios of securities to assets. Moreover, this pattern is largely attributable to the smaller banks. Their results support the existence of a "bank lending channel" of monetary transmission, though they do not allow us to make precise statements about its quantitative importance.

Peek and Rosengren (2000) use the Japanese banking crisis as a natural experiment to test whether a loan supply shock can affect real economic activity. Because the shock was external to US credit markets, yet connected through the Japanese bank penetration of USS markets, this event allows one to identify an exogenous loan supply shock and ultimately link that shock to construction activity in U.S. commercial real estate markets. They exploit the variation across geographically distinct commercial real estate markets to establish conclusively that loan supply shocks emanating from Japan had real effects on economic activity in the United States.

Aggregate and financial shocks can affect the corporate sector by curtailing credit, including working capital and trade financing, to borrowers with valuable trading and investment opportunities (see Kashyap and Stein (1994) for a review). Real, financial or regulatory shocks can cause a real or perceived shortage of capital for banks. As a result, banks may become unwilling to lend even to viable companies and instead may prefer to invest excess liquidity in safe assets such as government 
WPS2854 Rich and Powerful? Subjective Power and Welfare in Russia
Michael Lokshin Martin Ravallion
June 2002

C. Cunanan 32301 
bonds. A credit crunch can originate from weak financial institutions or from tightened regulation and supervision. Increased uncertainty about whether and at what price loans will be available can also result in a shortage of loanable funds (Stiglitz and Weiss, 1981). These effects can be particularly severe for bank lending because banks are more likely than other financial intermediaries or markets to lend to firms that suffer from a greater degree of informational asymmetries.

In addition, a so-called balance sheet effect can further amplify the effect of shocks on corporations (see Bernanke and Gertier (1995) for a review). Ágénor and Aizenman (1999), ChanLau and Chen (1998), Kim and Stone (1999) in a domestic context and Greenwald (1999) in an international context show that generally weaknesses in the financial sector along with tighter regulation and supervision appear to contribute to corporate distress by curbing credit. Ding, Domac and Ferri (1998) and Ghosh and Ghosh (1999) provide some empirical evidence that tighter rules for financial institutions affected the supply of loanable funds in several countries. Changes in net worth of corporates were also likely to have been important in reducing the supply of financing.

Empirical research on identifying tools for the resolution and management of banking crises that are effective in resolving the crisis while limiting adverse economic spillover to the rest of the economy is sparse and most research in this area is limited to individual cases. Honohan and Klingebiel (2002) use cross-country evidence to determine whether specific crisis containment and resolution policies systematically influence the fiscal costs of resolving a crisis. They find that accommodating policies - such as blanket deposit guarantees, open-ended liquidity support, repeated recapitalizations, debtor bailouts, and regulatory forbearance - significantly increase fiscal costs of resolving a crisis. Claessens, Klingebiel and Laeven (2001) review the literature on crises resolution strategies. 


\section{Method}

We apply the method in Rajan and Zingales (1998) to investigate the link between external financial dependence and industrial growth during financial crises. Rajan and Zingales (1998) relate real growth in value added of a sector to an interaction term that includes a proxy for financial development and an index of external financial dependence. They show that firms that are relatively more dependent on external finance develop disproportionally faster in countries with moredeveloped or deeper financial markets, that is, they find a positive relation between the interaction term and real growth in value added.

Their index of external dependence is constructed at the industry level based on data of US firms. They choose the financial structure of US industries as their benchmark because the relatively opeñ, sophisiticated, and developed US finañcial markets should allow US firms to face the fewest obstacles to achieving their desired financial structure. This approach offers a valid and exogenous way to identify the extent of external dependence of an industry anywhere in the world under the assumption that there are technological and economic reasons why some industries depend more on external finance than others, and that these differences persist across countries. They also overcome some of the identification problems embedded in standard cross-country growth regressions by using an interaction between a country characteristic (financial development of a particular country) and an industry characteristic (external financial dependence of a particular industry) in addition to country indicators and industry indicators. This approach allows them to isolate the impact of financial development on industry growth after controlling for cross-country and within-country differences, and is therefore less subject to criticism about an omitted variable bias or model 
specification than traditional approaches. Our main innovation is to apply this approach to industries in countries experiencing financial crises to be able to investigate the real impact of shocks to the financial system in a country over time.

First, we estimate the basic model in Rajan and Zingales (1998) for our sample of countries (model 1).

$$
R V A G R_{i j}=C_{i}+I N D_{j}+\beta_{1} * S H A R E_{i j}+\beta_{2} * F D_{i} * E D_{j}+\varepsilon_{i j}
$$

where $R V A G R_{i j}$ is the real growth in value added of sector $j$ in country $i, C_{i}$ is a country dummy for country $i, I N D_{j}$ is an industry dummy for industry $j, S H A R E_{i j}$ is the share of sector $j$ in the total value added of country $i, F D_{i}$ is the development of the financial system of country $i, E D_{j}$ is the external dependence ratio of sector $j$ according to Rajan and Zingales (1998). The specification thus includes fixed country and industry effects. We use three alternative proxies for the level of financial development of a country: total credit to GDP, private sector credit to GDP, and M2 to GDP.

The main differences with the Rajan and Zingales (1998) setup is twofold. First, we estimate the model for two sub-periods, namely, before and during a financial crisis. When estimating the model for the crisis period, we use the pre-crisis levels of share in value added and our proxies for financial development to avoid potential endogeneity problems. Second, we estimate the model for crisis countries only, that is, for countries that are listed in Caprio and Klingebiel (2002) as havining experienced a financial crisis (and for which we have data). Note that by including country indicators into the regressions, we control for country-and industry-specifics. By including country 
indicators for the crisis period, we are effectively controlling for the general severity of the crisis in each country.

We are also interested in the link between the interaction of financial dependence and financial development on the one hand and the difference in real growth in value added between the crisis period and the pre-crisis period on the other hand. In an alternative specification of model (1), we therefore use the difference in real growth in value added between the crisis period and the precrisis period as a dependent variable.

$$
\triangle R V A G R_{i j}=C_{i}+I N D_{j}+\beta_{1}^{*} S H A R E_{i j}+\beta_{2}^{*} F D_{i}^{*} E D_{j}+\varepsilon_{i j}
$$

where $\triangle R V A G R_{i j}$ is the difference in real growth in value added of sector $j$ in country $i$ between the crisis period and the pre-crisis period. In other words, $\triangle R V A G R_{i j}=R V A G R_{i j, \text { crisis }}-R V A G R_{i j, \text { pre-crisis }}$, where $R V A G R_{i j, \text { crisis }}$ is the real growth in value added of sector $j$ in country $i$ during the crisis period and $R V A G R_{i j, \text { pre-crisis }}$ is the real growth in value added of sector $j$ in country $i$ during the pre-crisis period. To avoid potential endogeneity problems, we use the pre-crisis levels of share in value added and our proxies for financial development.

Because there may not be a linear relationship between the interaction term $F D_{i} * E D_{j}$ and the real growth in value added of sector $j$ in country $i, R V A G R_{i j}$, we also estimate the following model:

$$
R V A G R_{i j}=C_{i}+I N D_{j}+\beta_{1} * S H A R E_{i j}+\beta_{2} * F D_{i} * H i g h E D_{j}+\varepsilon_{i j}
$$


where $H i g h E D_{j}$ is a dummy variable for "High External Dependence" that takes value of one if sector $j$ is among the top-50\% of most financially dependent sectors of all sectors considered by Rajan and Zingales (1998), and zero otherwise. This setup provides a robustness check that controls for measurement error in the extemal dependence ratio of each sector estimated by Rajan and Zingales (1998). In other words, we may expect that the most financially dependent sectors show a different growth pattern in well-developed countries on average, but there may not necessarily be a different effect for the most financially dependent sector and the second most financially dependent sector. Similar to model (2), we also estimate the following model:

$$
\Delta R V A G R_{i j}=C_{i}+I N D_{j}+\beta_{1}^{*} S H A R E_{i j}+\beta_{2} * F D_{i}^{*} H i g h E D_{j}+\varepsilon_{i j}
$$

\section{Data}

The industry data is from Rajan and Zingales (1998). We use their measure of financial dependence by sector based on US firm-level data. Financial or external dependence is calculated as the fraction of capital expenditures not financed with cash flow from operations. The sectors considered by Rajan and Zingales (1998) are a mix of three-digit and four-digit ISIC (International Standard of Industrial Classification) level industries. Rather than use the mix of four-digit level sectoral breakdowns for some industries and three-digit level sectoral breakdowns for other industries in Rajan and Zingales (1998) is somewhat arbitrary, we use external dependence ratios for sectors on a three-digit ISIC level only. We therefore re-calculate the weighted average external dependence figure for the four-digit ISIC sectors on a three-digit İSIC level. For the sectors that are 
already on a three-digit ISIC level in Rajan and Zingales (1998), we simply use their external dependence figures. For the sectors that are not already on a three-digit ISIC level, we apply the same method as in Rajan and Zingales (1998) to financial data on US firms from Compustat to estimate external dependence figures. Table 1 lists the three-digit ISIC level external dependence figures across sectors in the United States during the 1980s. We use these external dependence figures to construct a high extemal dependence $\left(H i g h E D_{j}\right)$ dummy variable that takes value of one if sector $j$ is among the top-50\% of most financially dependent sectors, and value of zero otherwise. Similarily, we construct a low external dependence $\left(\operatorname{Low} E D_{j}\right)$ dummy variable that takes value of one if sector $j$ is among the bottom- $50 \%$ of most financially dependent sectors, and value of zero otherwise.

As measure of firm performance we use real growth in industry value added (annually compounded), the same measure as in Rajan and Zingales (1998). The data on value added for each industry in each country is obtained from the Industrial Statistical Yearbook database put together by the United National Statistical Division. The value added data are corrected for inflation using CPI data from the International Financial Statistics of the International Monetary Fund. We calculate the real growth in value added figures for sectors on a three-digit ISIC level as well. We also calculate the industry's share in total value added of the country, a variable used by Rajan and Zingales (1998).

Our measures of financial depth (total credit to GDP, private sector credit to GDP, and M2 to GDP) and the level of GDP per capita are from the International Financial Statistics of the International Monetary Fund.

We use the Caprio and Klingebiel (2002) data set to time crisis and pre-crisis periods. Since it is difficult to identify the crisis period precisely, we use $(t-1, t+1)$ as the crisis period, where $t$ is the first crisis year reported in Caprio and Klingebiel (2002). To ensure that the pre-crisis period is a 
distinct period not affected by the crisis, we separate the pre-crisis period from the crisis period by three years. We define the pre-crisis period to be $(t-8, t-4)$, if $t-8$ is available, otherwise as many years towards $t-8$ as possible, where $t$ is the first crisis year reported in Caprio and Klingebiel (2002). This restricts the pre-crisis period to a maximum of 5 years. We only allow for one crisis period in a country, which is the first crisis mentioned in Caprio and Klingebiel (2002), to avoid identification problems in case of recurring crises.

We started with the Caprio and Klingebiel (2002) data set of systemic banking crisis countries. This data set includes 113 banking crises from 93 countries since the 1970s. Due to data constraints we need to drop a large number of countries. First, we do not have data on sectoral value added for many crisis countries. Second, we exclude countries for which we do not have data for both the pre-crisis and the crisis periods. This excludes, for example, Poland for which we do not have data for the pre-crisis period. We also drop countries for which we do not have sectoral value added data for at least five sectors. This excludes Argentina, for which we have only data available for four sectors during the pre-crisis period. The final data set includes 19 crisis countries, including both developing and developed countries. Table 2 presents a list of these countries. For each country, the table also shows the average real growth in value added and the number of sectors during both the pre-crisis and crisis period. We do not investigate the post-crisis periods, because we do not have sufficient data on post-crisis years for many of the countries in the sample.

The number of sectors varies widely across countries from 10 sectors in Hungary to 28 sectors in Chile, Finland, Israel or Sweden. To ensure consistency in a country across periods, we examine the same sectors in both the pre-crisis and crisis periods. This excludes a number of sectors for several countries for which we could obtain data in only one sub-period. We note that this setup 
may lead to a potential selection problem because the data in the Industrial Statistical Yearbook is gradually becoming more comprehensive over time. Another potential selection effect would exist if entire sectors disappear during the crisis period. The latter is however not the case in our sample. Since we are interested in the difference in growth between the pre-crisis and crisis period, we need to use a balanced panel. The final data set contains a total of 448 sector-country observations from 19 crisis countries.

The number of firms within the sectors varies widely over time. In particular we see a large increase in the number of firms within certain sectors at certain points in time. This may be the result of a re-classification or the inclusion of firms that were previously excluded from the statistics on value added. In both cases, changes in value added are not related to firm performance, and such observations need therefore be excluded from the analysis. We have deleted all sectoral observations if the number of firms within the sector changed more than $+100 \%$ or $-50 \%$ (doubled or halved) between the pre-crisis and crisis periods. This criterion deletes around $5 \%$ of observations across the different sub-periods. We also have deleted observations if the real growth in value added exceeds $100 \%$, which excludes only a small number of cases.

Table 3 presents the summary statistics of some variables that indicate changes in real sector and financial sector activity for both the pre-crisis and during crisis periods. When comparing the summary statistics of the pre-crisis and crisis periods, we find the following crisis characteristics. During crises periods, on average countries experience lower real GDP growth, lower real growth in sectoral value added (both for sectors that are highly dependent on external finance and sectors that are not), lower real growth of M2, and lower growth of (private sector) credit. Financial crises thus 
are negatively correlated with real and financial sector activity and performance. These statistics aiso indirectly provide some reassurance about the appropriateness of the timing of the crisis periods.

Table 4 presents the pre-crisis levels of our proxies for financial development for our crisis countries. The financial development proxies indicate relatively low levels of financial development in countries like Bolivia, Chile, Columbia, and Mexico, and relatively high levels of financial development in Hungary, Japan, and Spain.

\section{Results}

First, we investigate the role of financial development on the link between external finance and sector growth for both pre-crisis and crisis periods. To this end, we estimate model (1) both for the pre-crisis period and the crisis period. The regression results are presented in panel A of Table 5. Each "pre-crisis" and "crisis" pair of columns uses a different measure of financial development. All standard errors are corrected for heteroskedasticity. Consistent with the findings in Rajan and Zingales (1998), we find for the pre-crisis "normal" period that financially dependent sectors grow on average disproportionally faster in countries with well-developed or deeper financial systems. In our sample, however, this result is statistically significant at the 10 percent level for only the total credit to GDP measure of financial development. This difference could partly be attributed to the fact that we have fewer observations than Rajan and Zingales (1998), since we focus on crisis countries. Another reason could be that we use external dependence figures on a three-digit level only. Our coefficient estimates for both the value-added share and the interaction term also are somewhat smaller than in Rajan and Zingales (1998).

During crisis periods, we find the opposite relationship, namely, that financially dependent 
sectors grow disproportionably slower in countries with well-developed or deeper financial systems. In none of our specifications, however, is the coefficient on the interaction term between financial depth and external dependence statistically significantly different from zero.

In Panel B of Table 5; we investigate whether the crisis relation differs from the pre-crisis relation by using the difference in real growth in value added between the crisis period and the precrisis period, $\triangle R V A G R_{i j}$, as dependent variable (model (2) in the previous section). As in Panel A we have three alternative specifications with each using a different measure of financial development. The reduction in growth rate from the pre-crisis period to the crisis period is larger for financially dependent firms in countries with well-developed financial systems. The coefficient of the interaction term is statistically significantly different from zero in two of the three specifications. In other words, financially dependent firms appear to be hit disproportionally by a financial crisis if they operate in countries with developed financial systems. The effect is economically significant. A one standard deviation increase in credit-to-GDP, for example, would reduce the difference in real growth in value added between the crisis period and the pre-crisis period by 1.0 percent (and the mean decline in real growth in value added between the crisis period and the pre-crisis period is 6.0 percent).

Next, we use a dummy variable that indicates high or low external dependence rather than a continuous variable (models (3) and (4) in the previous section). The regression results are presented in Table 6. The coefficient estimates and levels of statistical significance in Table 6 are very similar to those in Table 5. The main difference with the results in Table 5 is that in Panel B the interaction term between $H i g h E D_{j}$ and $F D_{i}$ is now statistically significantly different from zero in all three specifications. The results in Tables 5 and 6 suggests that in times of crisis there is a negative 
relationship between the interaction term of financial development or depth of the financial system and external dependence and real growth in value added.

\section{Data and Measurement Caveats}

We note a number of caveats and qualifications with respect to our analysis. First, there is the question on the reliability of data during crises. Many firm-level variables react with a lag to adverse shocks. Firm performance variabiles such as growth in value added tend to respond to financial crises with a lag. Perhaps growth in value added is not a good measure of firm performance, in particular during periods of crisis. In addition, financial development indicators such as credit to GDP tend to increase during periods of crises as GDP decreases to a larger extent than credit.

Second, determining the precise timing of crises is difficult, both in terms of identifying the beginning and the end of a crisis. A crisis may build up slowly and may not be resolved soon. Especially in the case of a typical $V$-shape pattern of recovery from a crisis it is crucial to get the timing right in order not to under- or overestimate the impact on firm performance. We use the data in Caprio and Klingebiel (2002) to define the beginning of a crisis and allow for a certain degree of mistiming by using a three year period around the Caprio and Klingebiel (2002) year as crisis period.

Third, measures for the size of the financial system relative to GDP may not be good proxies for financial development. During periods of credit booms, often preceding financial crises (see Kaminsky and Reinhart, 1999), for example, (private) credit over GDP may overstate the level of financial development or depth of the financial system. In addition, the political-economy of the policy responses to a financial crisis could affect the availability of credit in crises (see Kroszner (1998) and Klingebiel, Kroszner, Laeven and Van Oijen (2001)). 
Finally, one may question the appropriateness of the Rajan and Zingales (1998) proxy for financial dependence for our sample. Their approach uses US external dependence as proxy and assumes the same technological reasons that make a particular industry in the US more dependent on external finance than other industries in the US, also make this particular industry more dependent on external finance in all other countries around the world. Although this assumption is plausible, it may not hold for all countries for country-specific reasons. Many developing countries, for example, support certain industries through subsidies. These industries may be less dependent on external finance than without those subsidies.

\section{Conclusions}

In normal crisis periods we find that firms that are relatively more reliant on external finance grow disproportionaily faster in countries with deep financial systems consistent with Rajan Zingales (1998). When we examine crisis periods, however, we find the opposite relation: crises in the financial sector have a disproportionately negative impact on sectors that rely heavily on external sources of finance in countries with deep financial systems. Our results provide evidence on the mechanisms linking the financial and real sectors in a financial crisis.

We hypothesize that a deeper financial system allows sectors dependent on external finance to obtain relatively more external funding in normal periods, so a crisis would have a disproportionately negative effect on externally dependent firms in deeper financial systems. In

contrast, since externally dependent firms tend to obtain relatively less external financing in a shallower financial systems (hence the relatively lower growth rates in externally dependent sectors in such countries during normal times), a crisis in such countries has less of an effect on the growth 
of these sectors. In addition, it could also be that deeper financial systems are more efficient in enforcing hard budget constraints on firms during a financial crisis than are financial institutions in underdeveloped financial systems. 


\section{References}

Agénor, Pierre-Richard and Joshua Aizenman (1999), "Financial Sector Inefficiencies and Coordination Failures: Implications for Crisis Management", Policy Research Working Paper 2185, World Bank.

Beck, Thorsten, Ross Levine and Norman Loayza (2000), "Finance and the Sources of Growth", Journal of Financial Economics 58(1-2), 261-300.

Bernanke, Ben and Mark Gertler (1995), "Inside the Black Box: The Credit Channel of Monetary Policy Transmission", Journal of Economic Perspectives 9(4), 27-48.

Caprio, Jerry and Daniela Klingebiel (2002), "Episodes of Systemic and Borderline Financial Crises", In: Daniela Klingebiel and Luc Laeven (Eds.), Managing the Real and Fiscal Effects of Banking Crises, World Bank Discussion Paper No. 428, Washington, D.C.

Chan-Lau, Jorge A. and Zhaohui Chen (1998), "Financial Crisis and Credit Crunch as a Result of Inefficient Financial Intermediation - with Reference to the Asian Financial Crisis", Working Paper WP/98/127, International Monetary Fund, Washington, D.C.

Claessens, Stijn, Daniela Klingebiel and Luc Laeven (2001), "Financial Restructuring in Banking and Corporate Sector Crises: What Policies to Pursue?", NBER Working Paper 8386.

Demirgüç-Kunt, Asli and Vojislav Maksimovic (1998), "Law, Finance and Firm Growth", Journal of Finance 53(6), 2107 - 2137.

Ding, Wei, Ilker Domac and Giovanni Ferri (1998), "Is There a Credit Crunch in East Asia?", Asia Pacific Journal of Economics and Business 2(2), 4-32. 
Ghosh, Swati R. and Atish R. Ghosh (1999), "East Asia in the Aftermath: Was There a Crunch?", Working Paper WP/99/38, International Monetary Fund, Washington, D.C.

Greenwald, Bruce (1999), "International Adjustment in the Face of Imperfect Financial Markets", In: Proceedings of the World Bank Annual Conference on Development Economics 1998, World Bank, Washington, DC.

Honohan, Patrick and Daniela Klingebiel (2002), "The Fiscal Cost Implications of an Accommodating Approach to Banking Crises", Journal of Banking and Finance, Forthcoming.

Jayaratne, Jith and Philip E. Strahan (1995), "The Finance-Growth Nexus: Evidence From Bank Branch Deregulation, Quarterly Journal Of Economics 111(3), 639-70.

Kaminsky, Graciela L. and Carmen M. Reinhart (1999), "The Twin Crises: The Causes of Banking and Balance-of-Payments Problems", American Economic Review 89(3), 473500.

Kashyap, Anil and Jeremy Stein (1994), "Monetary Policy and Bank Lending", In: G. Mankiw (ed.), Monetary Policy, Chicago, 11l.: University of Chicago Press.

Kashyap, Anil K. and Jeremy C. Stein (2000), "What Do a Million Observations on Banks Say About the Transmission of Monetary Policy?", American Economic Review 90(3), 407-28.

Kim, Se-Jik and Mark R. Stone (1999), "Corporate Leverage, Bankruptcy, and Output Adjustment in Post-Crisis East Asia", Working Paper WP/99/143, International Monetary Fund, Washington, D.C. 
Klingebiel, Daniela, Randall S. Kroszner, Luc Laeven, and Pieter van Oijen (2001), "Stock Market Responses to Bank Restructuring Policies during the East Asia Crisis", Policy Research Working Paper 2571, World Bank, Washington, D.C.

Kroszner, Randall S. (1998), "On the Political Economy of Banking and Financial Regulatory Reform in Emerging Markets:, Research in Financial Services 10, 33-51.

Levine, Ross (1997), "Financial Development and Economic Growth: Views and Agenda", Journal of Economic Literature 35(2), 688-726.

Levine, Ross and Sarah Zervos (1998), "Stock Markets and Economic Growth", American Economic Review 88(3), 537-58.

Mishkin, Frederic S. (1977), "What Depressed the Consumer? The Household Balance Sheet and the 1973-75 Recession", Brookings Papers on Economic Activity 1, 123-64.

Peek, Joe and Eric S. Rosengren (2000), "Collateral Damage: Effects of the Japanese Bank Crisis on Real Activity in the United States", American Economic Review 90(1), 30-45.

Rajan, Raghuram G., and Luigi Zingales (1998), "Financial Dependence and Growth", American Economic Review 88(3), 559-96.

Stiglitz, Joseph E. and Andrew Weiss (1981), "Credit Rationing in Markets with Imperfect Information", American Economic Review 71(3), 393-410. 
Tă̄e 1 Externaī Dependence Across Industries în the United States During the 1980s

This table reports the median level of external financing for ISIC industries during the 1980's on a three-digit ISIC level. We use the classification of the second revision of the ISIC. External dependence is the fraction of capital expenditures not finance with cash flow from operations. Cash flow from operations is defined as in Rajan and Zingales (1998). For the sectors that are already on a three-digit ISIC level in Rajan and Zingales (1998) we simply use their external dependence figures. For the sectors that are on a four-digit ISIC levei in Rajan and Zingales (1998) we re-caiculate the weighted average external dependence figure for the four-digit ISIC sectors on a three-digit ISIC level using Compustat and the method in Rajan and Zingaies (1998).

\begin{tabular}{|c|c|c|}
\hline$\overline{I S I C}$ code & Industrial sector & External dependence \\
\hline 314 & Tobacco & -0.45 \\
\hline 361 & Pottery & -0.15 \\
\hline 323 & Leather & -0.14 \\
\hline 324 & Footwear & -0.08 \\
\hline 372 & Nonferrous metal & 0.01 \\
\hline 322 & Apparel & 0.03 \\
\hline 353 & Petroleum refineries & 0.04 \\
\hline 369 & Nonmetal products & 0.06 \\
\hline 313 & Beverages & 0.08 \\
\hline 371 & Iron and steel & 0.09 \\
\hline 311 & Food products & 0.14 \\
\hline 341 & Paper and products & 0.17 \\
\hline 321 & Textile & 0.19 \\
\hline 342 & Printing and publishing & 0.20 \\
\hline 355 & Rubber products & 0.23 \\
\hline 332 & Furniture & 0.24 \\
\hline 381 & Metal products & 0.24 \\
\hline 351 & Industrial chemicals & 0.25 \\
\hline 331 & Wood products & 0.28 \\
\hline 354 & Petroleum and coal products & 0.33 \\
\hline 384 & Transportation equipment & 0.36 \\
\hline 390 & Other industries & 0.47 \\
\hline 362 & Glass & 0.53 \\
\hline 382 & Machinery & 0.60 \\
\hline 352 & Other chemicals & 0.75 \\
\hline 383 & Electric machinery & 0.95 \\
\hline 385 & Professional goods & 0.96 \\
\hline 356 & Plastic products & 1.14 \\
\hline
\end{tabular}




\section{Table 2 Average Real Growth in Value Added for All Sectors Across Countries}

This table reports the real growth in sectoral value added averaged by country and for both pre-crisis and crisis periods, as well as the years of each sub-period and the number of sectors included. The during crisis period is $(t-1, t+1)$ where $t$ is the first crisis year reported in Caprio and Klingebiel (2002). The pre-crisis period is $(t-8, t-4)$, if $t-8$ is available, otherwise as many years towards t -8 as possible. The sample consists of a total number of 19 countries.

\begin{tabular}{lcccccc}
\hline & \multicolumn{3}{c}{ Pre-crisis } & \multicolumn{3}{c}{ During crisis } \\
\hline Country & $\begin{array}{c}\text { Real growth in } \\
\text { value added }\end{array}$ & Years & $\begin{array}{c}\text { Number of } \\
\text { sectors }\end{array}$ & $\begin{array}{c}\text { Real growth in } \\
\text { value added }\end{array}$ & Years & $\begin{array}{c}\text { Number of } \\
\text { sectors }\end{array}$ \\
\hline Bolivia & & & & & & \\
Chile & 0.046 & $1978-82$ & 21 & -0.079 & $1985-87$ & 21 \\
Colombia & 0.111 & $1970-72$ & 28 & 0.038 & $1975-77$ & 28 \\
Egypt & 0.061 & $1974-78$ & 27 & -0.038 & $1981-83$ & 27 \\
Finland & 0.042 & $1983-87$ & 24 & 0.032 & $1990-92$ & 24 \\
Hungary & 0.023 & $1983-87$ & 28 & -0.060 & $1990-92$ & 28 \\
Israel & 0.054 & $1983-87$ & 10 & -0.138 & $1990-92$ & 10 \\
Japan & 0.057 & $1970-73$ & 28 & 0.201 & $1976-78$ & 28 \\
Kenya & 0.054 & $1983-87$ & 27 & 0.012 & $1990-92$ & 27 \\
Malaysia & 0.049 & $1977-81$ & 23 & 0.038 & $1984-86$ & 23 \\
Mexico & 0.065 & $1977-81$ & 22 & 0.041 & $1984-86$ & 22 \\
New Zealand & 0.055 & $1974-78$ & 15 & 0.023 & $1981-83$ & 15 \\
Norway & -0.021 & $1979-83$ & 26 & -0.012 & $1986-88$ & 26 \\
Panama & -0.024 & $1979-83$ & 27 & -0.008 & $1986-88$ & 27 \\
Spain & 0.019 & $1980-84$ & 21 & -0.206 & $1987-89$ & 21 \\
Sweden & 0.108 & $1970-73$ & 25 & 0.131 & $1976-78$ & 25 \\
Turkey & 0.035 & $1983-87$ & 28 & -0.222 & $1990-92$ & 28 \\
Uruguay & 0.071 & $1986-90$ & 25 & 0.010 & $1993-95$ & 25 \\
Zimbabwe & 0.021 & $1974-77$ & 20 & -0.133 & $1980-82$ & 20 \\
& 0.055 & $1987-91$ & 23 & 0.006 & $1994-96$ & 23 \\
\hline
\end{tabular}




\section{Table 3 Summary Statistics Before and During Crisis}

Both for the pre-crisis and during crisis periods, this table list the summary statistics of the following variables: real growth in GDP, real growth in total credit, real growth in private credit, real growth in M2, real growth in value added of highly dependent (High ED) sectors, and real growth in value added of not-highly dependent (Low ED) sectors. The highly dependent sectors are those sectors that are among the top- $50 \%$ of most financially dependent sectors on a threedigit ISIC level according to Rajan and Zingales (1998). Similarly, the not-highly dependent sectors are those sectors that are among the bottom- $50 \%$ of most financially dependent sectors. The total sample includes 19 countries and 448 industry-country observations.

\begin{tabular}{lrrrrr}
\hline & Observations & Mean & Minimum & Maximum & Std Dev \\
\hline Before Crisis & & & & & \\
\hline Real growth in GDP & 19 & 0.052 & -0.003 & 0.160 & 0.040 \\
Real growth in Total credit & 19 & 0.118 & -0.055 & 0.641 & 0.161 \\
Real growth in Private Credit & 19 & 0.108 & 0.005 & 0.403 & 0.093 \\
Real growth in M2 & 19 & 0.088 & -0.040 & 0.494 & 0.125 \\
Real growth in value added of High ED sectors & 205 & 0.058 & -0.439 & 0.333 & 0.098 \\
Real growth in value added of Low ED sectors & 243 & 0.037 & -0.686 & 0.393 & 0.102 \\
& & & & & \\
\hline During crisis & & & & & \\
\hline Real growth in GDP & 19 & 0.005 & -0.076 & 0.150 & 0.047 \\
Real growth in Total credit & 19 & 0.096 & -0.150 & 0.736 & 0.227 \\
Real growth in Private Credit & 19 & 0.099 & -0.237 & 0.634 & 0.222 \\
Real growth in M2 & 19 & 0.066 & -0.206 & 0.460 & 0.157 \\
Real growth in value added of High ED sectors & 205 & -0.018 & -0.527 & 0.618 & 0.173 \\
Real growth in value added of Low ED sectors & 243 & -0.010 & -0.626 & 0.868 & 0.195 \\
\hline
\end{tabular}




\section{Table 4 Financial Depth Indicators}

This table reports total credit-to-GDP, private credit-to-GDP, and M2-to-GDP at the beginning of the pre-crisis period in each country. These variables are used as proxies for financial depth. Data are from the International Financial Statistics of IMF. Since the figures are for the first year of the pre-crisis period for each country, they are not directly comparable across countries. The pre-crisis years can be found in Table 2.

\begin{tabular}{|c|c|c|c|}
\hline Country & $\begin{array}{c}\text { Total credit-to-GDP } \\
\text { (pre-crisis) }\end{array}$ & $\begin{array}{l}\text { Total private credit-to-GDP } \\
\text { (pre-crisis) }\end{array}$ & $\begin{array}{l}\text { M2-to-GDP } \\
\text { (pre-crisis) }\end{array}$ \\
\hline Bolivia & $20.13 \%$ & $12.96 \%$ & $19.26 \%$ \\
\hline Chile & $17.20 \%$ & $8.32 \%$ & $15.24 \%$ \\
\hline Colombia & $24.41 \%$ & $14.69 \%$ & $19.76 \%$ \\
\hline Egypt & $98.79 \%$ & $26.02 \%$ & $82.57 \%$ \\
\hline Finland & $54.35 \%$ & $55.56 \%$ & $44.68 \%$ \\
\hline Hungary & $100.88 \%$ & $48.81 \%$ & $47.69 \%$ \\
\hline Israel & $50.52 \%$ & $29.94 \%$ & $51.32 \%$ \\
\hline Japan & $113.52 \%$ & $93.23 \%$ & $93.55 \%$ \\
\hline Kenya & $28.30 \%$ & $19.92 \%$ & $38.31 \%$ \\
\hline Malaysia & $31.49 \%$ & $27.74 \%$ & $45.95 \%$ \\
\hline Méxicó & $17.25 \%$ & $4.84 \%$ & $15.47 \%$ \\
\hline New Zealand & $31.32 \%$ & $21.57 \%$ & $29.44 \%$ \\
\hline Norway & $54.34 \%$ & $32.14 \%$ & $52.94 \%$ \\
\hline Panama & $61.57 \%$ & $54.36 \%$ & $34.53 \%$ \\
\hline Spain & $75.11 \%$ & $58.03 \%$ & $54.13 \%$ \\
\hline Sweden & $73.77 \%$ & $40.81 \%$ & $54.26 \%$ \\
\hline Turkey & $38.32 \%$ & $18.51 \%$ & $28.52 \%$ \\
\hline Uruguay & $23.79 \%$ & $18.51 \%$ & $18.08 \%$ \\
\hline Zimbabwe & $25.27 \%$ & $9.41 \%$ & $25.58 \%$ \\
\hline
\end{tabular}


Tab̄e 5 Vaiue Added Growth̆, Fìnanciaì Dependence, and Fìnanciaī Deveìopment: Before and During a Financial Crisis, With Continuous Financial Dependence Variable

Dependent variable in panel $A$ is real growth in value added of sector. Dependent variable in panel $B$ is the difference in real growth in value added between the crisis period and the pre-crisis period. Countries include Bolivia, Chile, Colombia, Egypt, Hungary, Spain, Finland, Hungary, Israel, Japan, Kenya, Mexico, Malaysia, Norway, New Zealand, Panama, Sweden, Turkey, Uruguay, Zimbabwe. Cut-off for difference in growth of number of firms within sector between sub-periods is $+100 \%$ and $-50 \%$ (doubled or halved). ED is the external dependency figure in Rajan and Zingales (1998) on a three-digit ISIC level (see Table 1). Country and industry dummies are included, but not reported. We use share in value added, total credit to GDP, private credit to GDP, and M2 to GDP for the first year of the precrisis period only. A constant was added, but is not reported. Heteroskedasticity-consistent standard errors between brackets. ${ }^{*}$ significant at $10 \%$ level; ${ }^{* *}$ significant at $5 \%$ level; ${ }^{* * *}$ significant at $1 \%$ level.

Panel A:

\begin{tabular}{|c|c|c|c|c|c|c|}
\hline Variable & Pre-crisis & Crisis & Pre-crisis & Crisis & Pre-crisis & Crisis \\
\hline Share in Value Added & $\begin{array}{r}* *-0.316 \\
(0.114)\end{array}$ & $\begin{array}{r}* *-0.554 \\
(0.211)\end{array}$ & $\begin{array}{r}* *-0.299 \\
(0.113)\end{array}$ & $\begin{array}{r}* * *-0.593 \\
(0.212)\end{array}$ & $\begin{array}{r}* *-0.298 \\
(0.115)\end{array}$ & $\begin{array}{r}* *_{-}-0.531 \\
(0.208)\end{array}$ \\
\hline ED * Total Credit to GDP & $\begin{array}{r}\star 0.072 \\
(0.043)\end{array}$ & $\begin{array}{r}-0.077 \\
(0.066)\end{array}$ & & & & \\
\hline ED * Private Credit to GDP & & & $\begin{array}{r}0.056 \\
(0.046)\end{array}$ & $\begin{array}{r}=0.016 \\
(0.071)\end{array}$ & & \\
\hline $\mathrm{ED} * \mathrm{M} 2$ to $\mathrm{GDP}$ & & & & & $\begin{array}{r}0.044 \\
(0.057)\end{array}$ & $\begin{array}{c}-0.164 \\
(0.099)\end{array}$ \\
\hline Prob $>F$ & $* * * 0.000$ & $* * * 0.000$ & $* * * 0.000$ & $* * * 0.000$ & $* * * 0.000$ & ${ }^{* * * *} 0.000$ \\
\hline R-squared & 0.207 & 0.384 & 0.204 & 0.382 & 0.204 & 0.388 \\
\hline Observations & 448 & 448 & 448 & 448 & 448 & 448 \\
\hline
\end{tabular}

Panel B:

\begin{tabular}{lrrr}
\hline Variable & Crisis vs. Pre-crisis & Crisis vs. Pre-crisis & Crisis vs. Pre-crisis \\
\hline & & & \\
Share in Value Added & 0.215 & 0.142 & 0.220 \\
ED * Total Credit to GDP & $(0.242)$ & $(0.240)$ & $(0.244)$ \\
& $* *-0.225$ & & \\
ED * Private Credit to GDP & $(0.111)$ & -0.124 & \\
& & $(0.103)$ & \\
ED * M2 to GDP & & & $* 0.280$ \\
& & & $(0.150)$ \\
Prob>F & & $* * * 0.000$ & $* * 0.000$ \\
R-squared & 0.000 & 0.288 & 0.295 \\
Observations & 448 & 448 & 448 \\
\hline
\end{tabular}




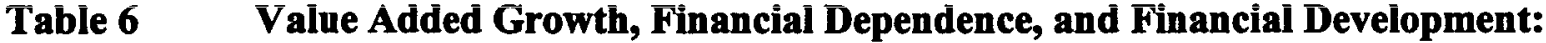 Before and During a Financial Crisis, With Dummy Variable Indicating High Financial Dependence}

Dependent variable in panel $A$ is real growth in value added of sector. Dependent variable in panel $B$ is the difference in real growth in value added between the crisis period and the pre-crisis period. Countries include Bolivia, Chile, Colombia, Egypt, Hungary, Spain, Finland, Hungary, Israel, Japan, Kenya, Mexico, Malaysia, Norway, New Zealand, Panama, Sweden, Turkey, Uruguay, Zimbabwe. Cut-off for difference in growth of number of firms within sector between sub-periods is $+100 \%$ and $-50 \%$ (doubled or halved). High ED indicates above median external dependence. Country and industry dummies are included, but not reported. We use share in value added, total credit to GDP, private credit to GDP, and M2 to GDP for the first year of the pre-crisis period only. A constant was added, but is not reported. Heteroskedasticity-consistent standard errors between brackets. ${ }^{*}$ significant at $10 \%$ level; ${ }^{* *}$ significant at $5 \%$ level; *** significant at $1 \%$ level.

Panel A:

\begin{tabular}{|c|c|c|c|c|c|c|}
\hline Variable & Pre-crisis & Crisis & Pre-crisis & Crisis & Pre-crisis & Crisis \\
\hline Share in Value Addâd & $\begin{array}{r}\Rightarrow=-0.337 \\
(0.115)\end{array}$ & $\begin{array}{r}=-0.555 \\
(0.216)\end{array}$ & $\begin{array}{r}\Rightarrow=-0.307 \\
(0.115)\end{array}$ & $\begin{array}{r}*=-0.551 \\
(0.217)\end{array}$ & $\begin{array}{r}*=-0.316 \\
(0.117)\end{array}$ & $\begin{array}{r}*=-0.547 \\
(0.217)\end{array}$ \\
\hline High ED * Total Credit to GDP & $\begin{array}{r}* 0.062 \\
(0.034)\end{array}$ & $\begin{array}{r}-0.055 \\
(0.059)\end{array}$ & & & & \\
\hline High ED * Private Credit to GDP & & & $\begin{array}{r}0.043 \\
(0.037)\end{array}$ & $\begin{array}{r}-0.070 \\
(0.061)\end{array}$ & & \\
\hline High ED * M2 to GDP & & & & & $\begin{array}{r}0.050 \\
(0.044)\end{array}$ & $\begin{array}{r}-0.076 \\
(0.077)\end{array}$ \\
\hline Prob $>F$ & $* * * 0.000$ & $* * * 0.000$ & $* * * 0.000$ & $* * * 0.000$ & $* * * 0.000$ & $* * * 0.000$ \\
\hline R-squared & 0.210 & 0.384 & 0.205 & 0.384 & 0.205 & 0.384 \\
\hline Observations & 448 & 448 & 448 & 448 & 448 & 448 \\
\hline
\end{tabular}

Panel B:

\begin{tabular}{|c|c|c|c|}
\hline Variable & Crisis vs. Pre-crisis & Crisis vs. Pre-crisis & Crisis vs. Pre-crisis \\
\hline Share in Value Added & $\begin{array}{r}0.227 \\
(0.244)\end{array}$ & $\begin{array}{r}0.193 \\
(0.241)\end{array}$ & $\begin{array}{r}0.216 \\
(0.245)\end{array}$ \\
\hline High ED * Total Credit to GDP & $\begin{array}{r}\star^{*}-0.139 \\
(0.068)\end{array}$ & & \\
\hline High ED * Private Credit to GDP & & $\begin{array}{r}* *_{-0.144} \\
(0.068)\end{array}$ & \\
\hline High ED * M2 to GDP & & & $\begin{array}{l}*-0.158 \\
(0.090)\end{array}$ \\
\hline Prob $>\mathbf{F}$ & $\because \div 0.000$ & $* * 0.000$ & $\neq \neq \div 0.000$ \\
\hline R-squared & 0.294 & 0.291 & 0.292 \\
\hline Observations & 448 & 448 & 448 \\
\hline
\end{tabular}


WPS2837 Reform, Growth, and Poverty in Vietnam

WPS2838 Economic Mobility in Vietnam in the $1990 \mathrm{~s}$

WPS2839 Marketing Externalities and Market Development

WPS2840 Public Spending and Outcomes: Does Governance Matter?

WPS2841 Contractual Savings in Countries with a Small Financial Sector

WPS2842 Financial Secior ineefficiencies and the Debt Laffer Curve

WPS2843 A Practical Guide to Managing Systemic Financial Crises: A Review of Approaches Taken in Indonesia. the Republic of Korea, and Thailand

WPS2844 Money Demand in Venezuela: Multiple Cycle Extraction in a Cointegration Framework

WPS2845 The Spatial Division of Labor in Nepal

WPS2846 Is India's Economic Growth Leaving the Poor Behind?

WPS2847 The Nature and Dynamics of Poverty Determinants in Burkina Faso in the 1990s

WPS2848 Administrative Barriers to Foreign Investment in Developing Countries

WPS2849 Pooling, Savings, and Prevention: Mitigating the Risk of Old Age Poverty in Chile

WPS2850 Determinants of Commercial Bank Performance in Transition: An Application of Data Envelopment Analysis

WPS2851 Economic Development and the World Trade Organization After Doha

WPS2852 Regional Agreements and Trade in Services: Policy Issues

Jacques Morisset

Olivier Lumenga Neso

Truman G. Packard

David A. Grigorian

Vlad Manole

June 2002

May 2002

May 2002

May 2002

May 2002

May 2002

June 2002

M. Geller

85155

F. Shilpi

87476

C. Cunanan 32301

P. White

81131

Mi. Feghali 36177

T. Packard 75841

S. Torres 39012

Bernard Hoekman

Aaditya Mattoo

Carsten Fink

Donald Cox
June 2002

June 2002

June 2002
P. Flewitt 32724

P. Flewitt 32724

E. Khine 37471 